\title{
Revisiting the Debate on Open Marxist Perspectives
}

\author{
Pinar Donmez \& Alex Sutton
}

Published in British Journal of Politics and International Relations 18:3 (2016)

\section{Word Count: 8299}

\begin{abstract}
This article seeks to review the recent incarnation of a long-standing engagement in international political economy (IPE) and critical theory between open Marxist perspectives (OMPS) and their critics. The paper aims to identify the enduring relevance of this debate in order to constructively think about the possibility and future of critical social inquiry in our time. It criticises elements on both sides of the debate that no longer serve but rather hinder achieving this objective. We argue that the recent criticisms make a number of important constructive points that could help enhance the explanatory power of OMPs yet still portray the latter uncharitably. We propose to take the emphasis on openness in OMPs seriously as a scholarly and political orientation without immersing the debate with the charges of reductionism, instrumentalism, determinism and functionalism which are frequently raised by various versions of Marxism against one another - often to little avail.
\end{abstract}

\section{Introduction}

In this paper our key objective is to revisit a long-standing scholarly debate to explore and assess the possibility and future of critical social inquiry within politics and international studies- an endeavour initiated originally by Bieler and Morton (2003: 467) in the early 2000s. To this end we aim to review and critically engage with a number of criticisms (Bruff, 2009; Bieler et. al., 2010; Tsolakis, 2010; Susen, 2012; Elden and Morton, 2015) directed against a heterogeneous body of scholarship which has come to be identified as open Marxismi. These criticisms have focused on OMPs' explanation of the dynamics of international political economy and the interaction between globally-defined capital and the territorially-defined state-form. They take issue with the ways in which both the object and method of inquiry (Roberts, 2002) are defined according to OMPs and pose thought-provoking questions with regards to the possibility of critique and critical theory broadly understood. These critiques, which we present under four main categories in due course following their proponents' categorisation, represent the latest incarnation of an on-going critical engagement (Barker, 1978; Lacher, 2002) between the two theoretical strands which arguably take their common starting point in the Marxist critique of social relations and social inquiry.

With particular reference to the more recent wave of criticisms, we argue that they make a number of important constructive points that could help enhance the explanatory power of OMPs but portray the latter uncharitably. We further argue that a similar representation can also be found in the first wave of criticism. This representation takes the form of a tendency to equate OMPs to orthodox Marxism. Indeed, this is the red thread binding these critiques together, impacting on their constructive value which has had quite a considerable effect on the tone and 
value of the debate between OMPs and their critics not unlike the debates of previous decades in critical social theory. "It should be added that responses from OM scholars have similarly reciprocated this tone in tackling the criticisms which has ultimately reproduced the previous debates and led to an unproductive impasse.

Given the current level of the debate between OMPs and their critics, particularly neoGramscian approaches, it seems odd to recall that collaborative work was undertaken by authors from both perspectives (Bieler et al. 2006). Indeed, the debate has now ossified to such an extent that not only does collaborative work now seem unlikely but dialogue itself has broken down. More importantly the manner in which the debate evolved has forestalled the further development of critical theory in IPE and IR as originally intended by its proponents. A recent example of this debate can be observed in the exchange between between Greig Charnock (2010:1283, 1295-1296), who identifies the work of Henri Lefebvre as compatible with OMPs in challenge of the regulation approach and new state spatialities literature, and Stuart Elden \& Adam Morton (2015:1f1), who accuse Charnock of claiming exclusive "proprietorship" over Lefebvre's work. iii We do not mean to claim that any and all criticism is unfair but that the nature of the criticism, through uncharitable readings and the conflation of differing perspectives, diminishes the quality of the debate.

This is not to suggest that this debate is no longer meaningful, or that it has been resolved to everyone's satisfaction. On the contrary, in this paper we intend to emphasise and draw attention to the importance of this debate for the scholarship as a whole and to trace the possibilities of how productive dialogue between two important strands of radical thought may resume on this basis.

To achieve this, we emphasise which criticisms in fact address the challenges of Marxist theorising, critical theory and empirical inquiry as a whole and which are specifically aimed at OMPs. We intend to position the open Marxist critique of mainstream and other Marxist approaches while clarifying its purpose and boundaries. In doing so we hope the nature of this critical engagement could move away from a pattern where each side of perspectives pull the other towards the contours of their frameworks of reference and push back when these efforts fail. Instead the two vantage points could be acknowledged and delineated in a manner which would enrich rather than undermine one another. Finally we conclude with the implications of this critical dialogue between these critical IR/IPE theories on the possibility and the future of critical theory and social empirical inquiry. This is deemed particularly important as related to the analyses of the recent and on-going global crisis, which present theoretical and methodological challenges and should provoke new forms of thinking within the study of critical political economy.

The paper begins by outlining the current critiques of OMPs which is followed by an account of open Marxism that responds to these criticisms in a constructive fashion before outlining the significance of this debate more broadly. The goal of this paper is to emphasise the importance of openness and historical enquiry to critical social theory, and particularly the 
Marxist tradition with an understanding that these two strands of radical scholarship have as many commonalities as differences to be able to build more constructively on furthering the debates and struggles of emancipation in contemporary capitalism. We do not argue that differences should be overlooked, and criticisms side-lined but rather that they should not be allowed to overshadow the common basis on which OMPs and their critics stand so that future scholarly exchanges can expand the horizons of this debate meaningfully.

\section{Four objections in two directions, or two objections in four forms?}

In a fashion similar to and almost mirroring the debates of Marxist theorising on capitalist state and state-society relations in the past ${ }^{\mathrm{iv}}$, the initial as well as the latest lines of critique advanced by scholars present four main objections against open Marxist perspectives:

1. A "reluctance to develop a historicised account of the uneven and combined development of capitalism", which is problematic as it does not explain the development of capitalism within already extant, pre-capitalist territorial structures, states (Bieler et. al., 2010:27)

2. The rejection of historical periodization as a means of identifying capitalist development. (Bieler et. al., 2010:27)

3. A "residual state-centrism within Open Marxism, which is anchored in a view of the state as a de facto functional guarantor of the rotation of capital and securer of the conditions of capital accumulation" and prioritising the "dominant reproduction of capitalism over resistance" (ibid.; Bieler and Morton, 2003: 469, 475; Tsolakis, 2010:389; Bieler \& Morton 2013:29)

4. A determinism concerning revolutionary change based on the assumption that the capitalist state is doomed to collapse. This is based on the idea that social change is itself driven by individual revolutionary acts rather than collective action. (Bieler and Morton, 2006:161-162; Bieler et. al., 2010:27) $)^{v}$

It could be noted that the earlier critiques (Bieler and Morton, 2003) were detailed and balanced in their specific targets of criticism within OMPs but the tone of the critiques has changed more drastically in the recent debate (Bieler et. al. 2010) ${ }^{\mathrm{vi}}$. Nevertheless the articulation of open Marxist and neo-Gramscian perspectives as "competing historical materialist perspectives within IPE" has been a shared starting point of both the initial and latest wave of critiques. The above critics reach these conclusions following an inquiry into the "foundations of Open Marxism" (ibid:26; Bruff, 2009:333). In our view, however, the representations of OMPs in these criticisms suffer from a lack of acknowledgment of the heterogeneous character of this scholarship and conflating "foundations" with subtleties in individual scholars' perspectives. The character of the latest debate also reflects frequent uses of argument from analogy by both sides which aim to point out to perceived methodological and conceptual issues relating to uses and abuses of abstraction (Bonefeld, 2009; Bruff, 2009, Bieler et. al. 2010). We believe that it is vital to approach such frequent usage of analogies with caution and acknowledge their limitations since, despite their 
discursive strength, they may risk averting our attention from the key areas of consideration and dispute.

In various accounts (Bieler \& Morton 2003; Bruff, 2009; Bieler et. al., 2010), the aforementioned problems are argued to stem from an elemental issue underlying and intrinsic to OM: a "totalising ontology" which conceives capitalist social relations as the "single constitutive source" of human activity (Bieler and Morton, 2003: 473; Bruff 2009:333). This point echoes an earlier critique where abstraction in OMPs is argued to be reduced to the "constituting power of labour within a mode of production" with an "almost exclusive concern with the capital-labour relation" (Roberts, 2002: 98, 101). Coupled with the charges of state-centrism and functionalism that correlate the purpose and function of state action to the maintenance of capitalist social relations, critics suggest that the issue of pre-capitalist social formations and the varieties of capitalism and state forms they detect in different historical periods and territorial contexts present themselves as aspects of social reality unacknowledged and unaccounted for within the ranks of OMPs (Bieler and Morton, 2003: 474). This is further epitomised in the concept of "epistemological austerity" inherent in OMPs (Bruff, 2009:334, 337-339).

Bruff (ibid.) in particular attributes to OMPs a latent essentialism and a tendency towards totalisation through a careful tracing and interpreting of particular phrasing and wording allegedly indicative of determinism (such as "derive", "need", "inherently") within the works of a number of scholars who have been homogeneously identified as Open Marxists. Rather than taking into account the heterogeneous approaches within OMPs, authors are clumped together such that one author's view must be shared by all OMPs. As such, Bruff concludes that OMPs offer a determinist and totalising ontology in their account of capitalist social relations as inherently contradictory in nature (ibid.). This line of critique is very much in line with the initial wave of criticisms charging OMPs of producing "a variant of 'Theological Marxism"' (Bieler and Morton, 2003:160-1). vii

A closer look into these objections also reveals that there are two distinct directions that link the first two points on the one hand and the final two points on the other. The argument against the alleged reluctance within OMPs to pay close attention to the pre-capitalist transition into capitalism appears to resonate well with the criticism against its subsequent refusal to provide a historical periodisation of capitalist development. Similarly the alleged state-centrism and functionalism detected in OMPs connects to the critique against determinism regarding social change which is also a point that links to the aforementioned objections on the basis of the role of history and a historicised methodology. Similar lines of criticism from OMPs have also been voiced against their critics in their response. Since this proves to be a largely unproductive intellectual exchange, the role of evident challenges at the heart of the theorising of state within Marxian schools of thought, not solely within its OM or Neo-Gramscian variant, should be emphasised here. They demonstrate the difficulties present in each strand of theorising of the state despite the fact that they appear in the form of individual charges directed from one perspective to another. 


\subsection{The Transition to Capitalism and the Absence of Historical Periodisation in OMPs}

The debates regarding the transition from feudalism to capitalism have long introduced fault lines within different Marxist approaches since their inception in the 1970s (Anderson, 1974; Brenner, 1977; Sweezy et. al., 1978; Holton, 1985: Burnham, 2002; Wood, 2002; Bieler and Morton, 2013). As Wood (2002: 30) notes, it represents an "irreducible contradiction... rooted in the nature of capitalism" itself.

It has also become one of the fundamental lines of critique against OMPs. This critique forms the key component of an alleged totalising ontology centred solely on capitalist social relations and its state-centrism. This is due to the purported correspondence between the functions of the capitalist state and the maintenance of capitalist social relations. In other words, the totalising nature of the open Marxist account of social relations leads to the state being inherently a capitalist state. Moreover, recent critics have claimed, following the first wave (Barker 1978:118), that open Marxism has not only failed to account for the historical development of the contemporary state system but argued that the contemporary state system can only be understood in terms of capitalist social relations (Bruff 2009:340; Tsolakis 2010:397; Lacher 2006:54). Bieler, Bruff and Morton (2010:28) maintain this criticism by arguing that Holloway (1991:231; 1994) understands the state only in terms of the development of global capitalist relations (see also Susen, 2012: 299 with respect to Holloway (2010)). viii They further support it through reference to Bonefeld's (2008:67) assertion that the modern state system and the capitalist mode of production developed at the same time, and in tandem. Their point, on the other hand, is that not all states developed as manifestations of capitalist relations but that capitalism emerged into an already-existing state system.

The contemporary relevance of the transition debate for criticisms charged against OM rests more on the alleged ahistoricism and reluctance to distinguish between "different forms of state" and develop "a periodisation of the capitalist mode of production" (Bieler and Morton, 2003: 474i 2006: 161, Bruff, 2009:339-340). The main motivation here, and rightfully so, appears to be the need for conceptual tools for the analysis of peripheral, developing capitalist countries where the likelihood of the co-existence of pre-capitalist and capitalist forms of social relations is higher than in the case of the particular case of English capitalism and state (Wood, 2002: 21-22). An additional and related motivation is also to theorise "the international", which is to say the multiplicity of states, adequately within a Marxist framework without losing sight of a theory of the state. OMPs are argued to have failed in providing such theoretical tools due to their alleged conviction that capitalist social relations and the national state system developed simultaneously and complementarily (Bruff, 2009:340; see also Tsolakis, 2010:397-8).

Bruff re-iterates his critique outlined in the first section along these lines to suggest that open Marxism puts forward not a "historical determination" (quoting Bonefeld, 1993: 21) but a "universal-within-historical determination of all social relations by capitalist social relations" now that the latter is the "constitutive source of human social practice in capitalist societies" (ibid.:339, emphasis added). It is unclear how such a reading of the OM scholarship could be upheld from existing scholarly works without adhering to and building upon Bruff's initial criticism of "totalising ontology" within OMPs. The critique is furthered with reference to another quotation ${ }^{\text {ix }}$ 
which was interpreted to mean "that all other social relations, which in the pre-capitalist era may have been constitutive of human activity, have in effect been dissolved-and even if they continue to exist in capitalist societies, they do so as nothing more than expressions of the class struggle" (ibid.: 340, emphasis added). With reference to the transition debate and the non-correspondence of the evolution of the global capitalism and territorial state system, the conclusion is that "Open Marxism ignores the possibility that human social practice is constituted by elements other than simply the need to extract surplus value from labour." (ibid.).

Either the criticism offered is that OMPs reject the existence of states prior to the development of capitalism, or that the mode of production exists somehow separately from the state. The former would be an absurd claim and a very uncharitable interpretation of OM accounts of the state and its historical development, the latter is a deeply problematic reading of the historical development of capitalism that necessarily separates the economic and political facets of social relations - the very antithesis of a Marxist account of social relations. The problem of historical periodization within capitalism derives directly from this point. OMPs' critics have suggested that absolutism, a transitional social form, existed between feudalism and capitalism (Bieler \& Morton 2013:30; Morton 2005:497i Teschke 2003:74). This distinct period saw the formation of the sovereign state and the modern state system; however, the authors argue this period took place "before the emergence and spread of capitalism" (Bieler \& Morton 2013:30). The identification of this peculiar transitional society, however, raises within Marxist historical materialism a question about why absolutism needs to be identified as a distinct historical epoch and if so how its relationship with social relations of production is established. In other words, why is it not, for example, presented as the nascent manifestation of capitalist social relations?

This point of criticism has been directed before (Barker, 1978:118; Lacher, 2002:153; Roberts, 2002: 88) problematising the international/national linkages and the conflation from the singular and abstract (capital relation/ state) to the plural and concrete (capitalist social relations/ states) as detected in OMPs. With reference to Holloway and Picciotto (1978), Barker notes that the scholars treat the state "as if it existed only in the singular" (1978: 118). Lacher (2002: 153) similarly emphasises that "that the capitalist state does not exist in the singular but as one among many is thus not directly given by the capital relation". It is worth noting that Lacher's own views of historical materialism diverge from the Marxist tradition in a number of key ways (Burns 2010:236). Indeed, Lacher (2006:31) rejects the importance of the mode of production to the historical materialist method as well as to an understanding of the state system. Tony Burns (2010:240) also criticises Lacher for arguing that just because the development of capitalism and the international state system may have been contingent rather than necessary (an assertion that Lacher attributes to all Marxists), it does not mean that they are not related. Rather, whether in Burns' view or not, we contend that the open Marxist account takes the view that the development of the state system and capitalist social relations was contingent but inextricably linked. It is perhaps best to understand this in terms of Marx's own characterisation of historical development in The $18^{\text {th }}$ Brumaire: 
"Men make their own history, but they do not make it as they please; they do not make it under self-selected circumstances, but under circumstances existing already, given and transmitted from the past. The tradition of all dead generations weighs like a nightmare on the brains of the living. And just as they seem to be occupied with revolutionizing themselves and things, creating something that did not exist before, precisely in such epochs of revolutionary crisis they anxiously conjure up the spirits of the past to their service, borrowing from them names, battle slogans, and costumes in order to present this new scene in world history in time-honored disguise and borrowed language" ([1852] 2012:1)

Following Marx, it could be argued that capitalism was not born into a vacuum but instead into an already existing society. So, too, with the state and, indeed, Marx himself makes this point directly in On The Jewish Question ([1843] 2010:14) by articulating how the capitalist state now constitutes a different form of relations between people. Marx ([1858] 1993:107) later developed this point in a broader sense:

"Since, furthermore, bourgeois society is but a form resulting from the development of antagonistic elements, some relations belonging to earlier forms of society are frequently to be found in it but in a crippled state or as a travesty of their former self, as e.g. communal property. While it may be said, therefore, that the categories of bourgeois economy contain what is true of all other forms of society, the statement is to be taken cum grano salis. They may contain these in a developed, or crippled, or caricatured form, but always essentially different."

In essence, therefore, the OM account of the transformation from feudalism to capitalism maintains the emphasis Marx placed upon understanding the complexity of social life more broadly. Social relations have to be contextualised in terms of their historically conditioned circumstances; however, they can only be understood in the here and now in terms of the capitalist mode of production in all of its inherent antagonisms and contradictions (Marx [1859] 1971:20-21; Bonefeld 2009, 2014:166). Once this is understood, history then stops being a "collection of dead facts" (Marx [1845] 1998:43). OMPs, despite their heterogeneity in their treatment of a number of issues of common concern for Marxist theorising as a whole, emphasise this explicitly in their eponymous embrace of openness: the content and form of class struggle is not pre-determined.

The general OM account of state development is not to deny its existence prior to the development of capitalism, nor is it to say that the state exists independently of social relations, but instead that the state only exists in and through temporally- and spatially-conditioned social relations. As such, to say that capitalism was born into an already-developed state-system is as analytically helpful as saying that capitalism was born into an already-developed international trading system.

A helpful basis for describing the OM understanding of the state is to consider Marx's 
characterisation of apparently transhistorical phenomena:

"Proudhon and others naturally find it very pleasant, when they do not know the historical origin of a certain economic phenomenon, to give it a historicophilosophical explanation by going into mythology. Adam or Prometheus bit upon the scheme cut and dried, whereupon it was adopted, etc. Nothing is more tediously dry than the dreaming locus communis... Whenever we speak, therefore, of production, we always have in mind production at a certain stage of social development, or production of social individuals." ([1858] 1993:84-85)

And again

"The bourgeois economy furnishes a key to ancient economy, etc. This is, however, by no means true of the method of those economists who blot out all historical differences and see the bourgeois form in all forms of society. One can understand the nature of tribute, tithes, etc., after one has learned the nature of rent. But they must not be considered identical" ([1858] 1993:106)

The important point to take here is not that the state did not exist prior to the existence of capitalism but this was not, obviously, a manifestation of the capitalist mode of production. The state is not a transhistorical entity; moreover, to consider the modern state system as something that is not somehow linked to the characteristic of social relations as a whole is deeply problematic, especially from a historical materialist standpoint. Therefore it seems more sensible to conceive that the emergence of capitalist social relations transformed pre-existing entities into contemporary capitalist states. Undoubtedly, this retained a phantom of their pre-capitalist form hence the particular national character of these states. The geographical organisation of, particularly European, states conforms to ancient (yet still arbitrary) divisions - which in our view comprises the rationale for pursuing historical enquiry within OMPs. With respect to the analysis of economic policymaking in Britain, Kettell (2004: 24) articulates this point clearly in noting that alongside the constraints imposed by the capitalist state form and class struggle, "the various political, economic, cultural, and ideological attributes of the particular state in question" need to be taken into account in order to comprehensively understand the underlying dynamics of particular contexts.

Form-analysis seeks to understand the variety of forms that capitalist social relations take; however, this does not necessitate rejecting commonalities. Nor does it suggest that all types of assessment of different periods/stages and forms of capitalist social relations within or outside OMPs are problematic or prone to reification. Typologies of state and stages of capitalist development are problematised by OMPs as potentially side-lining the significance of class struggle and capitalist social relations in the analysis of the complexity of social life (Clarke 1992). The goal of OMPs instead is to understand how class struggle manifests in the particular historical circumstances within and through which the state exists (Burnham 2006:79-81). 


\subsection{The Structural-Functionalist Account of the State and Determinism Regarding Social Change}

The underlying logic behind this dual line of critique of OMPs, as Tsolakis (2010:393-4) puts it, lies in the definition of the state solely in regard to its function in capitalist social relations. In criticising Burnham's understanding of the state, Tsolakis notes that "the state, as a regulative, well-defined complex of institutions, always sustains the abstract discipline of the world market by upholding the 'general interest' of capital against particular corporative interests and against labour demands" (ibid.:394). Moreover he contends that OM "often conceptualises the state as unitary and free from internal contradictions and struggle (a territorial entity)... by virtue of its own disciplining by world money" (ibid.).

We contend that the very fact that class struggle rests at the heart of OMPs means that the state is conceived of as fundamentally contradictory: its functions cannot be carried out successfully. Indeed, this criticism supposes that the interests of capital-in-general can be understood unambiguously, and that strategies in pursuit of them can even be meaningfully measured in terms of success or failure in a transhistorical fashion. Both of these points are explicitly rejected by OMPs (Burnham 1994b; 2006, Kettell, 2008). It is also worth considering that OMPs' use of form-analysis clearly rejects the functionalist account of the state, instead inclining towards adopting what Burnham (1994b: 5) refers to as the "organisational" view of the state. This view of the state derives first and foremost from social relations, from which we can then understand how and why the state tends to behave in the way that it does. The criticism of functionalism presents this back to front: one assumes the state has a function and from this one can perceive the hand of capital everywhere. This criticism, then, can be characterised as anachronistic - a throwback to the Miliband-Poulantzas debate.

The Miliband-Poulantzas debate perhaps set the terms and tone of much theorising of the state and subsequent debate in Marxist theory leading to inherited issues which are currently under criticism in this paper in the context of the OM/non-OM debate. In its predominantly accepted, and for some misconstrued form, the (non-) debate (Jessop, 2008: 149) was between an instrumentalist perspective that favours the overpowering nature of capitalist elites upon the state and structuralist perspective conceiving the state as structurally determined by the overall characteristic of the social formation within which it operates (Clarke, 1991: 19-20). With hindsight there has been a recent appreciation of the subtleties of the debate beyond the simplistic and formulaic assessments (Wetherly et. al., 2008). It has been acknowledged that both scholars in fact explored the different aspects of the problem employing different methods and focus, both perspectives carried pitfalls and shortcomings within themselves and that scholars attempted to overcome these limitations in their later works towards a non-reductionist analysis (Poulantzas, 1978a; 2000, Wetherly et. al., 2008).

Returning to the contemporary debate with OMPs on this basis, it should be emphasised that OMPs place an emphasis on the state's management of the role of money, labour and interstate relations due to the very fact that it arises out of these contradictory social relations and appears autonomous from them (Bonefeld, Brown, Burnham, 1995: 166). However, in line with 
the points made by Roberts (2002: 91-99) regarding the role of abstraction in Marxist theory, it should be noted that the level of abstraction in the specification of the state-form is not the same as the specification of state management (Burnham 1995: 102), and more precisely, statecraft (Burnham 1994a:5; 2007). Therefore it fails to extend beyond the standard charges made within different Marxist strands against one another, as OMPs do not suggest that the functions are fulfilled completely and without contradiction and disruption.

Bieler et al. (2010:27) criticise OMPs for state-centrism and, as with Tsolakis (2010), also condemn OM's characterisation of the state as a "functional guarantor" for capital accumulation. This undoubtedly derives from an account by OM authors of states as "regulative agencies" in the reproduction of global capitalist society (Burnham 2001a:110; see also Clarke 1983:118). This representation, however, fails to treat fairly the point that these regulative agencies are seen by OMPs not solely as regulating the reproduction of society by acting in the interests of capital-in general, which they cannot definitively know or act on, but rather they are first and foremost understood as moments of social reproduction themselves which preclude immediate moments of closure and resolution to contradictions (Clarke 1983:118). Indeed, this point is further clarified by Burnham (2006:80):

"The relation between the state and the reproduction of capital is a complex one and it cannot be assumed, in a functionalist manner, that the state is simply 'determined' by capital or that everything the state does will be in the best interests of capital"

As Panitch (1994: 65) similarly adds:

"To speak in terms of functions is not necessarily improperly 'functionalist' insofar as the range of structures that might undertake their performance, and the conditions which might mean their non-performance, are explicitly problematised"

In fact, for OMPs, the state has a plethora of strategies available to it with which to manage social relations, each of which has to be contextualized under very particular historical and geographical circumstances as also noted in the previous section (Holloway 1995:121). Moreover, as the state is seen as a manifestation of capitalist social relations, which are inherently contradictory, these strategies are not successful in perpetuity and require continuous adaptation and change. These changes have been characterized by $\mathrm{OM}^{\prime}$ 's critics at a level of abstraction different from OMPs as either typologies of state, or stages of capitalist development.

The criticism that OMPs conceive of the state as a unitary political actor seems hard to accept, especially given the work of a number of scholars in determining the various struggles over policy (Burnham 1990, 2003; Bonefeld 1993; Kettell 2004; Rogers 2012). Bieler \& Morton (2013:29) also make the claim that, while authors such as Burnham, Kettell and Rogers produce interesting work, they do not offer a "class analysis but [revert] back to the state-centrism so characteristic of mainstream IR". This seems a particularly unconstructive critique given the class analysis built into the methodology of these works and a clear acknowledgment of the form- 
analytical characteristic of capitalist state. Peter Burnham (2006:81) explicitly acknowledges and addresses how OM's abstraction must be complemented by historical analysis, and the analytical value that can be derived from it:

"The high-level abstractions of state theory and the circuitry of capital are essential in helping to clarify the key political economy problems which beset modern governments, but the twists and turns of the policymaking process can only be revealed by close empirical study of government personnel at particular moments ... It is important therefore that the component parts of the 'state' are disaggregated to reveal the struggles that took place and alliances that were formed among the key actors."

Rather than perpetuating these lines of critique and mutual accusation, we would like to emphasise that both approaches in fact retain their starting point in the Marxist theorising of state and social relations and provide insights into different yet complementary and equally valid aspects of critical social inquiry. They both also retain shortcomings in common with Marxist theorising of state. Tsolakis (2010: 388) suggests that both OM and neo-Gramscian approaches do not directly specify the state as a terrain of struggle between different social forces and fractions of capital, endowed with the kind of contradictions brought by these internal/domestic actors and forces. In that sense it is true that OM does not treat the state as such, which could be considered as a strength, especially in comparison with perspectives that often use such a position to propose the so-called neutrality of the liberal pluralist state. However, this does not mean that the state-form itself is devoid of internal contradictions. Quite the contrary. Various concrete manifestations of these internal contradictions can be found in the specific analyses of statecraft and governing strategy (Burnham, 2001; 2007; 2011; Kettell, 2004; Rogers, 2009). Following the logic of critique employed by OM critics, Tsolakis' emphasis on conceiving of the state as a site of struggle whilst at the same time endowing it with a strategic selectivity to the point where the state "may be temporarily dominated by fractions of capital... or labour" may risk instrumentalising it rather than becoming a definitive solution to OM's alleged structuralfunctionalism (2010: 396). Conceived in this manner, the choice seems to be between "capitalist state" or "state in capitalist society". Again, this line of critique recreates older debates and -isms within Marxist thought, and coerces one to take sides with one or the other instead of rejecting this false dichotomy and conceptualising both moments within the state-form (ibid.).

The conceptualisation of the state as a manifestation of capitalist social relations means that OMPs are at least sceptical of claims that the state can be a force for emancipatory social change, and at most totally rejects such claims. Bieler at al (2010:32-34) criticise the philosophy of revolution in $\mathrm{OM}$ as indistinguishable from the egocentric philosophy of Max Stirner. This criticism is established through close reading of the work of, principally, Psychopedis (2005) and Holloway (2005a; 2005b). Susen (2012: 311) similarly charges Holloway's (2010) approach of engaging with all possible -isms as outlined above. On this basis a further criticism is derived (Bruff 2009a, 2009b; Bieler at al. 2010) that OM rejects transhistorical qualities of human existence. This seems particularly galling from a Marxist historical materialism, especially given 
the preference of the critics to quote from The German Ideology ([1845] 1998:2), which emphasises that "whenever we speak, therefore, of production, we always have in mind production at a certain stage of social development, or production of social individuals."

Regardless of the particular criticisms that could be directed against these assessments in terms of their understanding of OMPs, we would like to emphasise that there is considerable variation among the individual perspectives of scholars within broader OMPs and specific, relevant points of critique and objections are certainly needed to move the debate and dialogue forward. To re-iterate our core argument, constructive critical engagement is hindered when broad generalisations and conflation are proposed on the basis of specific scholarly assessments.

\section{In Defence of Openness and the Implication for Critical Social Theory}

Before initiating a response to the aforementioned two directions of critique, which take their starting point from the argument that OM rests upon a "totalising ontology", it is crucial to delineate the shared premises of $\mathrm{OM}$ as a whole rather than generalising from the individual differences of viewpoints. As noted earlier the body of work under scrutiny is heterogeneous and it should be treated as such. This is an often-adhered sensitivity by the proponents of NeoGramscian analysis, who characterise their works under the term of "perspective" and "approach" rather than a "school" or an "-ism." Contrastingly in the case of OMPs, the critics themselves tend to totalise diverse views and perspectives at times and present a line of critique where different and often divergent views of scholars are argued to produce an incoherent and inconsistent general theory of capitalist state and social relations.

The alleged state-centrism and functionalism of $\mathrm{OM}$ is criticised referring in particular to works such as Burnham (2001), Kettell (2004; 2008), Rogers (2009). Simultaneously the fluidity and imprecision (i.e. excessive openness) of the OM concepts and the absence of a socially embedded theory of revolution are criticised with reference to the works of Gunn (1992), Holloway (2005a; 2005b) and Psychopedis (2005) in particular. This is particularly striking given the fact that Bieler et. al. (2010) criticise the selective citation of Gramsci and retreat to analogies by Bonefeld (2009) in his response to the points raised by Bruff (2009). Even though critics could view these divergent aspects as internal inconsistencies within OMPs, it nevertheless yields an all too convenient and generic line of critique. These subtleties tend not to be acknowledged and OMPs come to be dismissed on the broad grounds that any other theoretical perspective (let alone Marxist) could be judged.

To avoid such shortcomings it is crucial to have a contextual account of OMPs since critical ways of understanding society cannot be divorced from political strategies of emancipation and transformation. Therefore the emergence and evolution of conceptual frameworks are influenced by the political and ideological orientation and strategies of different Marxist interpretations in transcending capitalist social relations within different historical contexts. This holds true also for the motivations of the recent criticism of OM. It is important, then, to come to terms with why the state-form has been conceptualised in a way which would yield criticisms in terms of its close 
association with capitalist social relations and the alleged inflexibility to acknowledge the latter's pre-capitalist inheritance.

Following the principle of contextualisation that OM scholars applied in the case of placing Gramsci's thought within historical perspective (Burnham 1991), it is worth noting that the global crisis of the late 1970 s was seminal in the emergence and development of OM. This derived from the exacerbation of the problems within existing socialist countries and their repercussions on theory on the one hand and the issues intrinsic to the social democratic project and larger emancipatory political practice in Europe. Whilst both the Soviet experience and social democratic political practice suggested the possibility, albeit in different forms, that the state apparatus could be taken over and transformed for emancipatory ends in transforming capitalist social relations, the reality increasingly seemed to be proving these assumptions wrong in the context of the 1970s. The limitations set against state action due to the dynamics of capitalist accumulation were a recurring theme of the Conference of Socialist Economists (CSE) that ultimately gave birth to the development of open Marxist perspectives (Clarke, 1991). In such a context, it is not surprising that themes of capitalist crisis and the workings of the capitalist state to stave off the effects of crisis have been the preliminary starting point and focus of debate and theorising within OMPs. Its close interaction with various then-prominent Marxist strands of thought from its very inception also made the OM's critical streak particularly pronounced from the very start.

Having provided this brief contextualisation, Bieler and Morton's characterisation emerges as a reasonable starting point in order to fulfil the task of delineating the aforementioned shared premises of the heterogeneous OM perspectives. They characterise open Marxism as a 'critical theoretical questioning of taken-for-granted assumptions about the social world and the practical conditions of dominance and subordination in capitalism' (2003:468). While it seems likely that all varieties of Marxism would make claim to the same critical credentials, open Marxist perspectives' value lies in their starting point and its critical reappraisal of the class antagonism between capital and labour.

OMPs' openness derives from an acknowledgement of the fluidity and unpredictability of social relations, particularly class struggle. This openness is certainly a response to the determinism of structural Marxism (Bieler and Morton, 2003: 470) but reflects a more significant acceptance of how class struggle manifests in myriad and unexpected ways (Bonefeld et al. 1992:xvi). As such, openness also refers to the exploration of social categories in order to comprehend the social relations that underlie them (ibid.). However, stemming from this acceptance of openness is a reliance on historical enquiry: an acknowledgement that only the study of history can reveal to students of social relations the ways in which class struggle can and has manifested. This aspect of open Marxist thought can be seen as clearly grounded upon Marx's own musings on his historical materialist method.

Most of the aforementioned critiques have been directed against an allegedly totalising ontology of OM at its source as noted earlier. However, the alternative proposals appear to 
involve historical periodisation of capitalist development, introduction of various categories of different types and forms of states. This pluralises the conceptual tools and/or introduces distinct categories in order to account for the specificity of each moment and form of broader social relations. This can be more accurately identified as a golden mean, or Goldilocks, fallacy in which OM's theoretical practice is found epistemologically austere and an infinite pluralisation of heuristics is equally found to be undesirable but a middle point is considered to be "just right."

The crux of this rather esoteric, but still important, debate is the fact that it addresses the vital question of the possibility and conditions of critique in social theory. When stripped from the particularities of the OM vs. Neo-Gramscian (or broadly non-OM) debate, a broader discussion could be determined in terms of the implications on the nature, boundaries and method of critique in the field of IR/IPE as well as more generally in social theory and political practice (for a recent in-depth assessment in this vein, Bonefeld, 2014).

The rationale of critics in their quest to introduce myriad analytical tools of explanation to grasp the complexity of social reality is straightforward when the goal of inquiry itself is understanding and/or explanation. The challenge arises when the issue of critique is taken on board and elevated to become a key objective of inquiry especially given the fact that the concepts often tend to assume thing-like qualities and/or treated as such. The latter aspect in the act of theorising and devising conceptual tools is what progressively brings critique its internally connected dual character: critique of social reality and critique of the ways of theorising social reality when those theories fall into the aforementioned trap (Bonefeld, 2014, Chapter 2).

We believe this is where OM's approach to the abstract-concrete dialectic is the strongest and most useful as it forces us to continuously examine our approaches and perspectives with the same critical gaze we examine our objects of inquiry, applying the same criteria against reification. Indeed, this appears to be one of the major points of Bruff (2009): that OM does a lot of critiquing, very little explaining and to do well in the latter one needs his tools - and a lot of them. Against this background, OM could surely be criticised if it has indeed come to think that its abstract constructs fully correspond to concrete reality. However there is plenty of evidence from earlier and more recent OM scholarship to argue the opposite as outlined earlier. If anything, there seems to be remarkable caution shown by these works to avoid such forms of fetishisation to the point where critics would call it epistemologically austere.

On the basis of the four objections discussed in the first section of the paper, critics argue that OM conceives the concrete to be solely represented by its abstraction of capitalist social relations. Therefore, the critique is synchronised between a "totalising ontology" and "epistemological austerity" as the latter is linked to a more elemental form of reification of the abstract in concrete in OM. Bieler et. al. (2010) emphasise that the unresponsiveness of OM scholars toward these repeated critiques has ultimately made the OM standpoint difficult for them to constructively engage with. Moreover, concerns have arisen whether it could ever be conceived to be a plausible critical IR/IPE theory at all or be positioned rather as a "neo-realist moment within a Marxist perspective" (Bieler et. al., 2010: 29). To put forward such a critique, 
however, brings about the difficulty of settling accounts with the Marxist building blocks of OMPs as noted earlier if the latter's grounding in critical theory will not be denied altogether by the critics. $^{\text {xi }}$

Having elaborated these objections, it could be argued that they tend to move the line of critique toward that of Marxism as a whole rather than just OMPs. This would contribute to the continuation of constructive dialogue and debate between the perspectives if the critics framed the aforementioned criticisms as shared concerns and challenges of theorising state and social relations from within a Marxist framework. In its current form, however, the common ground the OMPs share with the different strands of critical theory remains unacknowledged and pulls the different sides of the debate further away from each other.

That is why it is crucial, in our opinion, to locate this debate and its seemingly "competing" sides within the common ground of critical theory and inquiry in order to direct it towards a more constructive path rather than allow it undermine each side on the basis of the charges of reductionism, instrumentalism, determinism, functionalism and not being truly or sufficiently critical. As is well known, such charges are frequently raised by various versions of Marxism against one another to little avail. In our view this calls for an urgent change in the approach and language of critical engagement within critical theory in IR/IPE if meaningful, creative responses to capitalist crisis and ways of advancing theory and practice of emancipation is to be thoroughly pursued.

\section{Conclusion}

In this paper, we aimed to revisit a long-standing scholarly debate on open Marxist perspectives to explore and assess the possibility and future of critical social inquiry within politics and international studies. Our focus, as such, has been on the value that can be provided by a substantial engagement with OMPs in particular. We argue that OMPs deserves the utmost credit for their specific contribution to and emphasis on the openness of our theoretical constructs. However, the latest critiques in particular tend to overlook and/or mischaracterise this aspect in a fashion that would discredit its applicability to the analysis of concrete empirical cases.

Instead of questioning or critiquing the theoretical and conceptual traditions on which the recent critics are based, we took the main lines of criticism on board in the subsequent sections of the paper and acknowledged the valid points of critique where applicable. We also demonstrated the unjustifiable and misplaced aspects of the reasoning behind some of the criticisms.

On this basis we argue that OMPs' central conception of critique and the abstract-concrete dialectic continues to assert the strongest resistance against diverse modes of fetishism and for this reason alone deserves to be treated seriously. The current circumstances of global crisis not only demystify the class character of social relations and state but also shake the ground upon which many widely held theoretical assumptions and frameworks, both mainstream and critical, have been historically built. 
As such, the emphasis on the organic conception of crisis and critique as well as the openness found in its critique will continue to be vitally useful and necessary so will a resumption of a constructive dialogue between different strands of critical theory. We would like to re-iterate our point from the introduction that these strands have as much in common as differences to be able to build more constructively on furthering the debates, struggles and strategies of emancipation.

\section{Bibliography}

Anderson, Perry (1974) Lineages of the Absolutist State London New Left Books

Barker, Colin (1978) A Note on the Theory of Capitalist States Capital \& Class 4

Bieler, Andreas, Werner Bonefeld, Peter Burnham and Adam David Morton (eds.) (2006) Global Restructuring, State, Capital and Labour: Contesting Neo-Gramscian Perspectives Palgrave London

Bieler, Andreas \& Adam David Morton (2003) Globalisation, the state and class struggle: a 'Critical Economy' engagement with Open Marxism British Journal of Politics and International Relations $5: 4$

Bieler, A., Bruff, I. \& Morton, A.D. (2010) Acorns and fruit: From totalisation to periodisation in the critique of capitalism Capital \& Class 34:1

Bieler, Andreas \& Adam David Morton (2013) The Will O The Wisp of the Transnational State, Journal of Australian Political Economy, 72

Bonefeld, Werner (2014) Critical Theory and the Critique of Political Economy: On Subversion and Negative Reason, Bloomsbury.

Bonefeld, Werner (2009) Society and Nature: some notes on Ian Bruff British Journal of Politics and International Relations 11:3

Bonefeld, Werner (2008) Global Capital, National State and the International Critique: Journal of Socialist Theory 36:1

Bonefeld, Werner and Kosmas Psychopedis (eds) (2001) The Politics of Change: Globalization, Ideology and Critique Palgrave Hampshire

Bonefeld, Werner, Alice Brown and Peter Burnham (1995) A Major Crisis?: The Politics of Economic Policy in Britain in the 1990s (Dartmouth Aldershot)

Bonefeld, Werner and John Holloway (eds) (1995) Global Capital, National State and the Politics of Money Macmillan London

Bonefeld, W., Gunn, R., Holloway, J. \& Psychopedis, K. (eds) (1995) Open Marxism Volume III: Emancipating Marx (Pluto Press London)

Bonefeld, W. (1993) The Recomposition of the British State during the 1980s (Aldershot: 
Dartmouth)

Bonefeld, W., Gunn, R. \& Psychopedis, K. (eds) (1992b) Open Marxism Volume II: Theory and Practice (Pluto Press London)

Bonefeld, W., Gunn, R. \& Psychopedis, K. (eds) (1992a) Open Marxism Volume I: Dialectics and History (Pluto Press London)

Bonefeld, W \& Holloway, J (eds) (1992) Post-Fordism and Social Form: A Marxist Debate on the Post-Fordist State Basingstoke: Palgrave Macmillan

Bonefeld, W (1987) Reformulation Of State Theory Capital \& Class 11:3, 96-127

Brenner, Robert (1977) The Origins of Capitalist Development: A Critique of Neo-Smithian Marxism New Left Review I 104

Bruff, Ian (200gb) The Totalisation of Human Social Practice: Open Marxists and Capitalist Social Relations, Foucauldians and Power Relations British Journal of Politics and International Relations 11:2

Bruff, lan (2009a) Assertions, Conflations and Human Nature: a Reply to Werner Bonefeld British Journal of Politics and International Relations 11:3

Burnham, Peter (2006) Marxism, the State, and British Politics British Politics 1

Burnham, Peter (2003) Remaking the Postwar World Economy: Robot and British Policy in the 1950 S Palgrave Macmillan London

Burnham, Peter (2001b) New Labour and the Politics of Depoliticisation British Journal of Politics and International Relations 3:2

Burnham, Peter (2001a) Marx, International Political Economy and Globalisation Capital \& Class 75

Burnham, Peter (1995) Capital, Crisis and the International State System in Werner Bonefeld and John Holloway (eds) Global Capital, National State and the Politics of Money Macmillan London

Burnham, Peter (1994b) The Organisational View of the State Politics 14:1

Burnham, Peter (1994a) Open Marxism and Vulgar International Political Economy Review of International Political Economy 1:2

Burnham, Peter (1991) Neo-Gramscian Hegemony and the International Order Capital \& Class 45

Burnham, Peter (1990) The Political Economy of Postwar Reconstruction Macmillan London

Burns, Tony (2010) Capitalism, Modernity and the Nation State: A Critique of Hannes Lacher Capital \& Class 34:2

Charnock, Greig, (2010) Challenging New State Spatialities: The Open Marxism of Henri Lefebvre, 
Antipode 42: 5

Clarke, Simon (1999) Capitalist Competition and the Tendency to Overproduction: Comments on Brenner's 'Uneven Development and the Long Downturn' Historical Materialism 4:1

Clarke, Simon (1994) Marx's Theory of Crisis Macmillan London

Clarke, Simon (1992) The Global Accumulation of Capital and the Periodisation of the Capitalist State Form, in Werner Bonefeld, Richard Gunn and Kosmas Psychopedis (eds.) Open Marxism Volume I: Dialectics and History Pluto Press London

Clarke, Simon (ed) (1991) The State Debate Macmillan London

Clarke, Simon (1983) State, Class Struggle and the Reproduction of Capital Kapitalistate 10:11

Elden S. and Morton A. (2015) Thinking Past Henri Lefebvre: Introducing "The Theory of Ground Rent and Rural Sociology", Antipode

Germain, R.D. (2007) Critical" Political Economy, Historical Materialism and Adam Morton, Politics 27:2

Gunn, R (1992) Against Historical Materialism: Marxism as First-Order Discourse, in Bonefeld, W., Gunn, R. \& Psychopedis, K. (eds) Open Marxism Volume II: Theory and Practice (Pluto Press London)

Hay C. (2006) State: Theories and Issues Basingstoke: Palgrave Macmillan

Holloway J. (2005a) No. Historical Materialism 13:4

Holloway J. (2005b) Change the World Without Taking Power: The Meaning of Revolution Today. London: Pluto

Holloway J. (2010) Crack Capitalism. London: Pluto

Holloway, John (1994) Global Capital and the State Capital \& Class 52

Holloway J., Picciotto S. (1991) Capital, Crisis and the State, in Clarke S (ed) The State Debate Basingstoke: Macmillan

Holloway, J. (1991) The State And Everyday Struggle, in Clarke S (ed.) The State Debate Basingstoke: Macmillan

Holloway, J (1988) The Great Bear, post-Fordism and class struggle: A comment on Bonefeld and Jessop Capital \& Class 36

Holloway, John and Sol Picciotto (1977) Capital, Crisis and the State Capital and Class 2

Holton, Robert J (1985) The Transition from Feudalism to Capitalism Houndsmill Macmillan

Jessop, B (2008) Dialogue of the Deaf: some Reflections on the Poulantzas-Miliband Debate, in Class Power and the State in Capitalist Society: Essays on Ralph Miliband (eds) P. Wetherly et. al. 
New York: Palgrave Macmillan.

Jessop, B (1988) Regulation Theory, Post Fordism And The State: More Than A Reply To Werner Bonefeld Capital \& Class 12:1 147-168.

Kettell, S (2008) Does Depoliticisation Work? Evidence from Britain's Membership of the Exchange Rate Mechanism, 1990-92 The British Journal of Politics \& International Relations 10:4

Kettell, S (2006) Circuits of Capital and Overproduction: A Marxist Analysis of the Present World Economic Crisis Review of Radical Political Economics 38

Kettell, S (2004) The Political Economy of Exchange Rate Policy-Making: From the Gold Standard to the Euro Palgrave Macmillan Hampshire

Lacher, Hannes (2006) Beyond Globalization: Capitalism, Territoriality and the International Relations of Modernity Routledge London

Marx, K and Engels, F (1998 [1845]) The German Ideology Prometheus Books New York

Marx, K (1971 [1859]) Contribution to the Critique of Political Economy Lawrence and Wishart London

Marx, K (1993 [1858]) Grundrisse: Foundations of the Critique of Political Economy Penguin New York

Marx K (2010 [1843]) On The Jewish Question

Morton, A D (2005) The Age of Absolutism: Capitalism, the Modern States- system and International Relations Review of International Studies 31:3

Morton, A.D. (2006) The Grimly Comic Riddle of Hegemony in IPE: Where is Class Struggle? Politics 26:1

Panitch L., (1994) Globalisation and the State Socialist Register, New York: MRP.

Poulantzas N., (2000) State, Power, Socialism London: Verso

Poulantzas N., (1978a) Classes in Contemporary Capitalism London: Verso

Psychopedis K (2005) 'Social critique and the logic of revolution: From Kant to Marx and Marx to us' in Bonefeld W, Psychopedis K (eds) Human Dignity: Social Autonomy and the Critique of Capitalism Ashgate Aldershot

Roberts M. J. (2002) "From Reflection to Refraction: Opening up Open Marxism", Capital \& Class, 26: 3 . 
Rogers, Christopher (2012) Managing Financial Crises: The IMF and Advanced Economies since 1976 Palgrave Basingstoke

Rogers, Christopher (2010) The Labour Government, the Treasury, and the $₫ 6$ Pay policy of July 1975 British Politics 5:2

Rogers, Christopher (200gb) From Social Contract to 'Social Contrick': the Depoliticisation of Economic Policy-Making under Harold Wilson 1974-75 British Journal of Politics \& International Relations 11:4

Rogers, Christopher (2009a) 'The Politics of Economic Policy Making in Britain: A Re-assessment of the 1976 IMF Crisis' Politics \& Policy 37:5

Soderberg, Johan and Netzen, Adam (2010) When all that is Theory Melts into (Hot) Air: Contrasts and Parallels between Actor Network Theory, Autonomist Marxism and Open Marxism Ephemera 10:2

Sutton, Alex (2015) The Political Economy of Imperial Relations: Britain, The Sterling Area, and Malaya, 1945-1960 Palgrave Basingstoke

Sutton, Alex (2013) Towards an Open Marxist Theory of Imperialism Capital \& Class

Teschke, Benno (2003) The Myth of 1648 Class, Geopolitics and the Making of Modern International Relations Verso London New York

Wetherly P. Barrow C. Burnham P., (2008) Class, Power and the State in Capitalist Society: Essays on Ralph Miliband New York: Palgrave

Wood, Ellen Meiksins (2002) The Origins of Capitalism: A Longer View Verso London

\footnotetext{
' We shall however be using the term open Marxist perspectives (OMPs) to be able to better reflect the heterogeneous character of this body of scholarship.

ii A particularly egregious example of the interaction between OM and neo-Gramscian authors can be found in the exchange between Bonefeld (2009) and Bruff (2009a; 2009b) in BJPIR 11:3. Indeed, this is an unproductive exchange, with little charity or solidarity from either author.

iii The particular exchange here is a good example of both the lack of charity in the debate. Elden \& Morton (2015:1fn1) clearly state that Charnock (in their sole reference to him) offers a good example of a "further troubling aspect" in "such Open Marxism" by claiming proprietorship over Lefebvre's work. However, Charnock (2010:1292) himself (on their page reference) merely claims "it is possible to derive a challenge to the structuralism-regulationism of the NSS literature from Lefebvre's writing on space, if we accept that Lefebvre's ideas are consistent with his open Marxist mode of critical thought". This is a very distinct and conditional claim to the one alleged by Elden \& Morton and could easily, we argue, have been taken more charitably. Thanks go to an anonymous reviewer for highlighting this point.

iv One indeed is reminded of the different aspects of the infamous Poulantzas-Miliband debate within the OMPs-NG debate despite the fact that, in the case of the former, it has long been acknowledged that
} 
there was more in common between both positions than differences (Jessop, 2008: 149; Holloway and Picciotto, 1991: 117; Hay et. al., 2006: 71).

'Soderberg and Netzen (2010:106) also make a criticism, following this same point, that open Marxists are antagonistic towards 'empirically oriented sociology'. This seems like a problematic claim given the works of Bonefeld et al. (1995) Burnham (1990; 2001b; 2003; 2006), Kettell (2004), Rogers (2009a; 2009b; 2010)

${ }^{v i}$ We would like to thank one of our anonymous reviewers for highlighting this point.

vii Adam Morton (2006:63-64) has previously, and quite rightly, criticized mainstream 'critical' IPE scholarship for its lack of engagement with class struggle, instead characterizing this writing as "liberal pluralist idealism". Ironically, Randall Germain (2007:128), offering an alternative and non-Marxist historical materialism, then portrayed Morton in the same way that Morton himself characterizes OM, describing his approach as a kind of "monological Marxism". In another example of scholarly parallels, Morton's own criticism of IPE mirrors that of Peter Burnham's (1994:221), who describes it as "a vulgar, fraudulent discipline".

viii Holloway (1991) was originally writing in terms of an exchange on similar issues between Jessop (1988) and Bonefeld (1987) in the journal Capital \& Class. These exchanges were ultimately published in Bonefeld \& Holloway (1992). See also Holloway (1988). Thanks go to an anonymous reviewer for suggesting this point.

ix "[h]istory is nothing but the movement of the class struggle" (Holloway, 1991: 236 quoted in Bruff, 2009: 340).

${ }^{x}$ However the content of this critique relies mainly on guilt by association in our view, deriving from Psychopedis' (2005:78) direct reference to Stirner and his influence on Marx's understanding of social change. Psychopedis' claim does not accept the ego-centrism of Stirner, rather his argument follows the form of Marx's own understanding of social change. Psychopedis (2005:88-92) also makes a number of references to Kant's contributions to the debate on social change but OM's critics have so far refrained from labeling OM a Liberal Idealist theory.

${ }^{x i}$ This could be explicitly seen in Bruff's "alternative" proposal of taking the transhistorical elements of human social practice, the need to produce, survive...etc, as the constitutive starting point and accept the multidimensional characteristics of sources of human practice despite still attributing a certain primacy over capitalist social practices within capitalist social formations (2009). For a critique see Bonefeld (2009). 